\title{
Transjugular Intrahepatic Portosystemic Shunt Combined with Haemoperfusion in an End-stage Renal Disease Patient with Liver Cirrhosis-related Refractory Portal Hypertensive Variceal Bleeding: A Case Report \\ $\mathrm{L} \mathrm{Li}^{1 *}, \mathrm{TL} \mathrm{Cui}^{1 *}, \mathrm{X} \mathrm{Li}^{2}, \mathrm{~F} \mathrm{Liu}^{1}$
}

\begin{abstract}
Transjugular intrahepatic portosystemic shunt (TIPS) is recommended as the second-line option for variceal bleeding in liver cirrhosis patients when the bleeding is not well controlled by medical and/or endoscopic therapy. However, due to a high incidence of post-TIPS hepatic encephalopathy, particularly in patients with end-stage renal disease (ESRD), TIPS is rarely used in such cases. We report a case involving the successful and safe use of TIPS combined with haemoperfusion to treat an ESRD patient with liver cirrhosis-related refractory portal hypertensive variceal bleeding. Our case suggests the possibility of inserting TIPS to stop recurrent variceal bleeding in ESRD patients with liver cirrhosis. Haemoperfusion may be used to reduce the risk of post-TIPS hepatic encephalopathy.
\end{abstract}

Keywords: End-stage renal disease, haemoperfusion, hepatic encephalopathy, liver cirrhosis, portal hypertensive variceal bleeding, transjugular intrahepatic portosystemic shunt

\section{Derivación Portosistémica Intrahepática Transyugular Combinada con Hemoperfusión en un Paciente con Enfermedad Renal en Fase Terminal con Sangramiento Variceal Refractario por Hipertensión Portal Relacionado con Cirrosis Hepática: Reporte de un Caso \\ $\mathrm{L} \mathrm{Li}^{1 *}, \mathrm{TL} \mathrm{Cui}^{1 *}, \mathrm{X} \mathrm{Li}^{2}, \mathrm{~F} \mathrm{Liu}^{1}$}

\begin{abstract}
RESUMEN
La derivación portosistémica intrahepática transyugular (DPIT) se recomienda como la opción de segunda línea para el sangramiento variceal en los pacientes de cirrosis hepática, cuando el sangrado no es bien controlado por tratamiento médico y/o endoscópico. Sin embargo, debido a la alta incidencia de la encefalopatía hepática post-DPIT, particularmente en pacientes con enfermedad renal en etapa terminal (ERET), DPIT es raramente utilizada en estos casos. Reportamos un caso que implica el uso exitoso y seguro de DPIT combinado con hemoperfusión para tratar a un paciente de ERET con sangramiento variceal refractario por hipertensión portal relacionado con cirrosis hepática. Nuestro caso sugiere la posibilidad de insertar DPIT para detener el sangrado recurrente por várices en los pacientes de ERET con cirrosis hepática. La hemoperfusión puede utilizarse para reducir el riesgo de encefalopatía hepática post-DPIT.
\end{abstract}

Palabras claves: Enfermedad renal en etapa terminal, hemoperfusión, encefalopatía hepática, cirrosis hepática, sangramiento variceal por hipertensión portal, +- derivación portosistémica intrahepática transyugular

West Indian Med J 2015; 64 (4): 452

From: ${ }^{1}$ Division of Nephrology and ${ }^{2}$ Division of Gastroenterology, West China Hospital of Sichuan University, Chengdu 610041, Sichuan, China.

Correspondence: Dr F Liu, Division of Nephrology, West China Hospital of Sichuan University, No. 37 Guoxue Alley, Chengdu, Sichuan 610041, China. Fax: 86-28-85422335; e-mail: liufangfh@163.com

*Co-first authors who contributed equally to the manuscript

\section{INTRODUCTION}

Liver cirrhosis is characterized by liver dysfunction and portal hypertension. Transjugular intrahepatic portosystemic shunt (TIPS) is the mainstay option for the management of portal hypertension-related complications in liver cirrhosis patients, including refractory and recurrent variceal bleeding when the patients are unresponsive to medical and/or endoscopic therapy 
$(1,2)$. Transjugular intrahepatic portosystemic shunt can improve renal function and significantly reduce the mortality in patients with recidivant ascites and in patients with better hepatic and renal function (3-5). However, due to a high incidence of post-TIPS hepatic encephalopathy, particularly in patients with ESRD, TIPS is rarely used in such cases. We report a case involving successful and safe use of TIPS combined with haemoperfusion in an ESRD patient with refractory liver cirrhosis-related portal hypertensive variceal bleeding and ascites.

\section{CASE REPORT}

A 65-year old woman diagnosed with diabetic nephropathy, ESRD and liver cirrhosis was transferred to our nephrology department for refractory ascites and recurrent gastrointestinal (GI) bleeding. In the past year, the patient had been admitted several times to a local hospital for refractory ascites and repeated variceal haemorrhage. Abdominal bloating was relieved by repeated volume paracentesis, and the GI bleeding was stopped by medical therapy. However, one month before admission, the patient complained of recurrent variceal bleeding that did not respond to proton pump inhibitors (PPIs), somatostatin or blood transfusion therapy. Laboratory tests showed that serum creatinine ( $\mathrm{sCr}$ ) had increased to 482.7 $\mu \mathrm{mol} / \mathrm{L}$ and haemoglobin had dropped to $47 \mathrm{~g} / \mathrm{L}$. Subsequently, the patient was transferred to our unit for further treatment.

On admission, physical examination showed the following: temperature $36.5^{\circ} \mathrm{C}$, respiratory rate $19 \mathrm{bpm}$, heart rate 59 bpm and blood pressure 161/64 mmHg. The patient looked pale and exhibited mild shortness of breath. Her abdomen was bulging, with an abdominal circumference of $120 \mathrm{~cm}$, and severe oedema was present in both extremities. Laboratory tests indicated haemoglobin level of $61 \mathrm{~g} / \mathrm{L}$ (normal reference values: $115-150 \mathrm{~g} / \mathrm{L}$ ), sCr level of $490 \mu \mathrm{mol} / \mathrm{L}$ (normal reference values: $37-110 \mu \mathrm{mol} / \mathrm{L}$ ) and an estimated glomerular filtration rate (eGFR) level of $7.47 \mathrm{ml} / \mathrm{min} / 1.73 \mathrm{~m}^{2}$. Hepatitis virus markers were negative. The levels of serum ammonia and liver function were normal. An ultrasound examination of the abdomen showed liver cirrhosis, splenomegaly, portal hypertension with a widened portal vein of approximately $15 \mathrm{~mm}$, and a large amount of ascites. The patient was diagnosed with diabetic nephropathy, ESRD, severe anaemia, heart failure, liver cirrhosis, portal hypertension-related ascites and variceal bleeding. The patient was placed on continuous venovenous haemofiltration $(\mathrm{CVVH})$ blood transfusion therapy and conventional medical therapy for GI bleeding with PPI, continuous infusion of somatostatin, carbazochrome sodium sulfonate and vitamin $\mathrm{K}$.
Twenty days later, the GI bleeding did not improve and existed persistently. Finally, TIPS (using an 8-mm diameter, 60-mm long covered stent; Fig. 1) was performed followed by CVVH. Two days after the procedure, the GI bleeding was completely alleviated and abdominal circumference dropped to $116 \mathrm{~cm}$ with normal liver function. The patient was discharged with maintenance haemodialysis (four hours of haemodialysis three times per week).

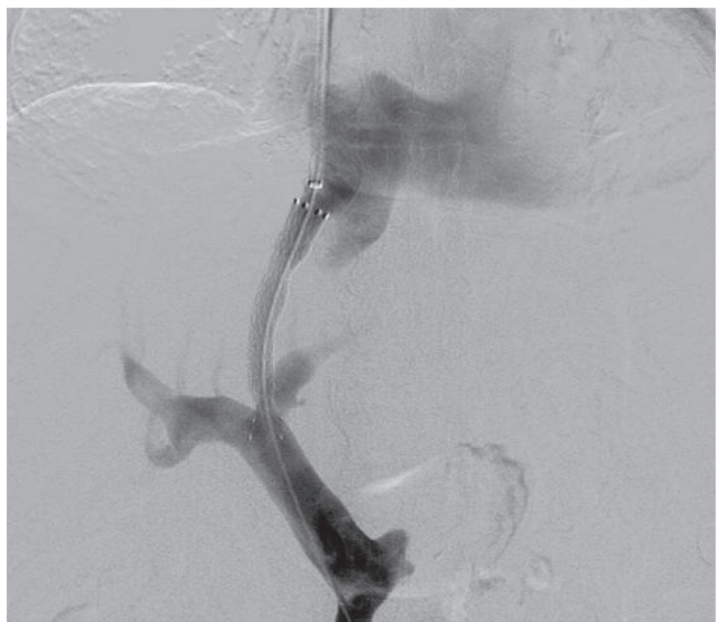

Fig. 1: Image after transjugular intrahepatic portosystemic shunt procedure (8-mm diameter, 60-mm long covered stent was successfully inserted).

One month after TIPS, the patient was readmitted because of limb tremor, abnormal verbal changes and irritability after constipation for two days. On admission, the level of serum ammonia was $59 \mu \mathrm{mol} / \mathrm{L}$ (normal reference values: 9$33 \mu \mathrm{mol} / \mathrm{L}$ ) and post-TIPS hepatic encephalopathy was diagnosed. The patient was placed on haemoperfusion combined with sustained low efficiency dialysis (SLED) and conventional therapy (low-protein diet, arginine, aspartic acid ornithine and maintenance of the volume and electrolyte balance). The symptoms improved following the treatment, and two days later, the level of serum ammonia decreased to 40 $\mu \mathrm{mol} / \mathrm{L}$. The patient was discharged and maintenance haemodialysis (two rounds of haemodialysis and one haemoperfusion per week) was recommended. Three months later, the patient returned to the unit for follow-up. The symptoms of hepatic encephalopathy had disappeared, and the patient reported feeling much better. The results of the patient's laboratory tests from the first hospitalization to the follow-up are shown in Fig. 2. 

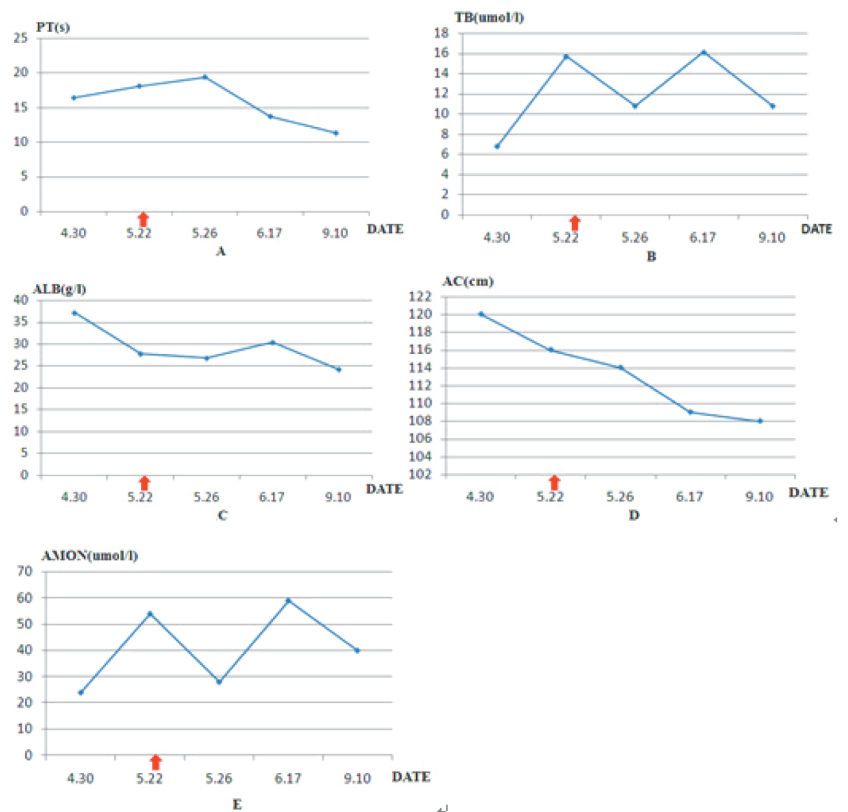

Fig. 2: Results of laboratory tests from the patient's first hospitalization to the follow-up. After transjugular intrahepatic portosystemic shunt (TIPS) combined with haemoperfusion, liver function and coagulation function improved, ascites caused by portal hypertension decreased and the serum ammonia level was reduced to a relatively low level. The red arrows represent the date TIPS was performed.

PT-prothrombin time; TB-total bilirubin; ALB-albumin; AC-abdominal circumference; $\mathrm{AMON}-\mathrm{ammonia}$

\section{DISCUSSION}

Liver cirrhosis-related recurrent variceal bleeding is a major and life-threatening complication of portal hypertension. Transjugular intrahepatic portosystemic shunt is recommended as the second-line option for variceal bleeding in liver cirrhosis patients who are not well controlled by medical and/or endoscopic therapy (2). However, the TIPS procedure may lead to some acute and chronic complications. Life-threatening complications include haemoperitoneum, haemobilia, liver ischaemia, cardiac failure and sepsis. Chronic post-TIPS complications include recurrent encephalopathy, congestive heart failure, portal vein thrombosis, progressive liver failure and stent dysfunction (6). Recurrent hepatic encephalopathy is one of the most common complications, especially in patients with renal insufficiency (7). Olde Damink et al (8) found that kidney function plays a major role in ammonia homeostasis after TIPS insertion. Transjugular intrahepatic portosystemic shunt patients have been shown to have reduced renal ammonia production levels and an increased role of renal excretion of ammonia. In 2008, Haskal and Radhakrishnan (7) assessed the safety, caution and encephalopathy risk for post-TIPS haemodialysis-dependent patients and patients with advanced renal insufficiency. The authors found that TIPS can be safely used in patients with ESRD to treat GI haemorrhage and refractory ascites. However, the risk of recurrent hepatic en- cephalopathy appears to be much higher than in patients with normal renal function. Thus, there have been rare reports of the use of TIPS to treat liver cirrhosis-related complications in ESRD or haemodialysis patients.

The present patient was diagnosed with ESRD, liver cirrhosis, portal hypertension-related ascites and variceal bleeding that was not responsive to conventional medical therapy. Because of the presence of severe anaemia and heart failure, peritoneal dialysis and endoscopic therapy were not prescribed. Excessive shunting of portal blood flow can induce the development of hepatic dysfunction and encephalopathy, so choosing an appropriate diameter of the stent is essential for balancing between efficacy with TIPS complications (9). In the present case, an 8-mm diameter, 60-mm long covered stent was used to reduce the portosystemic pressure and to prevent post-TIPS hepatic encephalopathy. After the operation and after the intermittent haemodialysis, the bleeding stopped dramatically; there were no postoperative complications, such as liver dysfunction or worsening heart failure, during the patient's hospitalization.

Consistent with previous studies (7), the risk of postTIPS hepatic encephalopathy is elevated in patients with ESRD. The present patient was readmitted because of hepatic encephalopathy induced by constipation. Based on the toxic hypothesis and the theory of neurotransmitters, the possibility of haemoperfusion was considered, and the treatment ultimately reduced the patient's serum ammonia. Regular haemoperfusion was then combined with a low protein diet, and lactulose was recommended to the patient as the maintenance therapy following TIPS. Four months after the first hospitalization, the patient's hepatic encephalopathy disappeared, and the level of serum ammonia decreased to $40 \mu \mathrm{mol} / \mathrm{L}$.

Considering the safety concerns, benefits, complications and contraindications for cirrhotic patients with ESRD undergoing haemodialysis when recurrent variceal haemorrhage is unresponsive to medical therapy, TIPS may be an effective and safe choice. Regular haemoperfusion combined with haemodialysis may be used to prevent post-TIPS hepatic encephalopathy.

This case report highlights the possibility of inserting TIPS to reduce portal hypertension to stop refractory gastrointestinal haemorrhage that is unresponsive to medical therapy in cirrhotic patients with ESRD undergoing haemodialysis. Regular haemoperfusion may be helpful for reducing the risk of post-TIPS hepatic encephalopathy.

\section{AUTHORS' NOTE}

Written informed consent was obtained from the patient for publication of this case report and any accompanying images. A copy of the written consent is available for review by the Editor of this journal. The authors declare that they have no competing interests. 


\section{REFERENCES}

1. Rossle M. TIPS: 25 years later. J Hepatol 2013; 59: 1081-93.

2. Boyer TD, Haskal ZJ; American Association for the Study of Liver Diseases. The role of transjugular intrahepatic portosystemic shunt (TIPS) in the management of portal hypertension. Hepatology 2005; 41: 386400 .

3. Anderson CL, Saad WE, Kalagher SD, Caldwell S, Sabri S, Turba UC et al. Effect of transjugular intrahepatic portosystemic shunt placement on renal function: a 7-year, single-center experience. J Vasc Interv Radiol 2010; 21: 1370-6. doi: 10.1016/j.jvir.2010.05.009. Epub 2010 Aug 5.

4. Albillos A, Bañares R, González M, Catalina MV, Molinero LM. A meta-analysis of transjugular intrahepatic portosystemic shunt versus paracentesis for refractory ascites. J Hepatol 2005; 43: 990-6.

5. Chen RP, Zhu Ge XJ, Huang ZM, Ye XH, Hu Cy, Lu GR et al. Prophylactic use of transjugular intrahepatic portosystemic shunt aids in the treatment of refractory ascites: metaregression and trial sequential meta-analysis. J Clin Gastroenterol 2014; 48: 290-9. doi: 10.1097/ MCG.0b013e3182a115e9.

6. Pomier-Layrargues G, Bouchard L, Lafortune M, Bissonnette J, Guerette $\mathrm{D}$, Perreault $\mathrm{P}$. The transjugular intrahepatic portosystemic shunt in the treatment of portal hypertension: current status. Int J Hepatol 2012; 2012: 167868. doi: 10.1155/2012/167868. Epub 2012 Jul 19.

7. Haskal ZJ, Radhakrishnan J. Transjugular intrahepatic portosystemic shunts in hemodialysis-dependent patients and patients with advanced renal insufficiency: safety, caution, and encephalopathy. J Vasc Interv Radiol 2008; 19: 516-20. doi: 10.1016/j.jvir.2007.11.011.

8. Olde Damink SW, Dejong CH, Deutz NE, Redhead DN, Hayes PC, Soeters PB et al. Kidney plays a major role in ammonia homeostasis after portasystemic shunting in patients with cirrhosis. Am J Physiol Gastrointest Liver Physiol 2006; 291: G189-94.

9. Qi XS, Bai M, Yang Z-P, Fan DM. Selection of a TIPS stent for management of portal hypertension in liver cirrhosis: an evidence-based review. World J Gastroenterol 2014; 20: 6470-80. doi: 10.3748/wjg. v20.i21.6470. 